\title{
Understanding gender differences in students' anxiety in a seminar presentation
}

\author{
Suardi Sahid*1, Aldiansyah $^{2}$, Iskandar ${ }^{3}$ \\ 1,3 Universitas Negeri Makassar, Makassar, Indonesia \\ e-mail: ${ }^{1}$ ardisahid123@gmail.com, ${ }^{3}$ iskandar@unm.ac.id \\ ${ }^{2}$ Indiana University of Pennsylvania, United States \\ e-mail: Ald_Lin@yahoo.co.id
}

\begin{abstract}
This paper discusses students` anxiety and gender differences faced by male and female in the presentation. The main focus is to see the anxiety affected by gender differences in a presentation at the State University of Makassar conducted in 2016, the subjects of this research were the students` at Graduate Program who conduct seminar presentation from September to the last of December. The researcher used purposive sampling by taking two males and two female students as a participant to be observed. The instruments that the researcher used were Observation checklist, field notes, and interview. The result of the research shows the significance related anxiety and gender differences which male anxiety is affected by their thought while female anxiety is affected by their feeling in a seminar presentation.
\end{abstract}

\section{Keywords:}

Anxiety; gender differences; seminar presentation

\section{INTRODUCTION}

Research on anxiety and gender differences has been hotly and creatively debated recently as an important aspect of linguistics- related research in areas such as psycholinguistics and sociolinguistics. Shibley,et al (2002: 150), note that anxiety is viewed as a subjective emotional state, and then by definition it can only be observed by the person experiencing it. In this case, the measurement of anxiety would have to rely exclusively on the person's selfreport of the emotional experience. If the emphasis is on the motoric system, the measurement will focus on overt behaviors such as facial expressions, escape, and avoidance. Finally, if anxiety is viewed in terms of physiological arousal, then measurement will focus on indicators such as heart rate and respiration. While each of these three measurement approaches has helped to advance our knowledge about anxiety, no single approach by itself provides a complete picture. Thus, anxiety is best viewed as a multifaceted construct that calls for measurement in several response systems (subjective, behavioral, and physiological), none of which uniquely defines anxiety.

Some research has been conducted on students` anxiety and gender differences in EFL class even in public speaking in western countries, for example in Turkey (Aydin 2008), Japan (Aida 1994), and United State (Chaplin 2009), other studies on students` anxiety and gender differences in 
Indonesia such as (Syarifuddin 2006, Arifin 2011, Fatmadewi 1998, Tutyandari 2005), have also discussed anxiety and significant differences to the gender of the participants.

The discussion of students' anxiety and gender differences in this paper is mainly based on Deborah Tannen theory which considers some variables which might affect the students ' anxiety toward gender differences, such as behavior and physically (1990: 88). One of the factors which influences students' anxiety in gender differences is social processes which occur throughout a person's lifetime. According to Tannen (1990: 43), male and female express themselves in different ways, and for a different reason, one of the most striking differences between the sexes is the unique ways that man and woman communicate. McLean \& Anderson (2009). Several different theoretical explanations have been proposed to account for gender differences in anxiety including gender role socialization, learned helplessness, strain theory, and reporting biases. The variables implicated by these theories have not been examined in integrated models. Understanding the extent to which potential mediating factors account for the relationship between gender and anxiety would foster the development of interventions that target essential risk mechanisms.

Calvarese (2015) stated that there were significant differences between males and females concerning their reactions to stress. Overall, more females experienced higher levels of depression, frustration, and anxiety than their male counterparts when reacting to stress. Males also tended to have other psychological reactions different from those listed on the survey. Also, while the stress reaction of anger was barely statistically insignificant, more females expressed anger than males as a reaction to stress.

Other research on language and gender also reveals women connect through conversation, while men connection through action, a psychotherapist, When a woman wants to talk, she wants to share emotions and thoughts, while a man generally shares ideas, suggestions, and facts and avoids talking about feelings, writes Goldsmith. That does not mean that a man will not talk about his feelings, but he might be uncomfortable while doing so. (Goldsmith 2013), in fact, Women use an abundance of non-verbal communication such as making eye contact, gesturing and animated facial expressions, psychotherapist Sherwood (2012), stated in her article, "a woman often prefers talking while sitting or standing in a cluster of people where everyone is faceto-face. A man prefers talking shoulder-to-shoulder in an angled pattern where he and his friends can take in the room. A woman might gesticulate, raise her eyebrows, incline her head and shrug her shoulders during the conversation. The man often prefers relaxed, sprawled pose and keeps the body language and facial expressions more contained (Sherwood 2012).

Another constellation of gender-linked beliefs centers on stereotypic ideas about emotional expression showed that women were believed to both experiences and express most emotions more readily than were men. Shibley et al. (2002: 507), from the 19 emotions examined, only anger and pride were more closely associated with men than women. Associated with women were emotions such as happiness, embarrassment, guilt, love, fear, and distress. The 
sex differences were perceived to be larger when the expression, rather than the experience, of emotion, was considered. People believe that both women and men suppress emotions when they are inconsistent with their appropriate gender role. As with research on other aspects of the gender belief system, cultural expectations provide a window through which others' emotional reactions are viewed.

Another difference is that women are more passive than men. If they are talking, they tend to show that they are not sure about what they are saying. In fact, women are different from men not only in verbal communication but also in nonverbal communication. One study by Griffin et al. (1999) looked at the use of nonverbal communication: eye contact, gestures, smiles, personal space, touch, and interpretation of nonverbal cues, and found that 67.5 percent of females establish more eye contact than men do; 75.5 percent use more gestures than males and 83.7 percent typically smile more often than a male does. This result shows that women are more comfortable using sensitive communicators than verbal communication.

Anxieties, simply in speaking, is a kind of troubled feeling in the mind and have both negative and positive effect and which motivated and facilitates learning. Furthermore, McIntyre and Gardner (1999: 284), defined language anxiety as the feeling of tension and apprehension. Specifically associated with second language context including, speaking, listening, and learning for girls, although enjoyment is a strong motivating force, anxiety is also of importance, as already mentioned. In both studies, more girls than boys expressed the view that they worked hard at things they enjoyed. In the second study, however, there was evidence that anxiety played a much greater role in influencing girls' efforts. Moreover, over half of the female sample, when asked how they dealt with anxieties about their progress, claimed that they reacted by working harder (Graham, et al 1995: 19), for girls, the removal of the pressure to 'perform' to a large audience would allow them to be more in command of the situation. Even more important, perhaps, is to consider the kind of learning activities that are presented to students.

This paper is going to explore the students ' anxiety in seminar presentation influenced by gender differences such as physically and behaviorally. Language anxiety as the combination of others anxieties that create a different from anxiety in language learning and there is a unique thing in language learning experience that makes some individual nervous (Harmer 1992).

\section{METHOD}

The method used in this research was qualitative descriptive research. The qualitative descriptive research was referred to survey research, determines and describes the way things were. Qualitative descriptive research was aimed to comprehend and enlighten the existing phenomena experienced by the subject of the research such as attitude, perception, motivation, action, etc, in a holistic way, and by describe it in words and language on expected particular context and by using such kinds of accepted method (Moleong, 2004).

The participants of this research were students at the Graduate English Program State University of Makassar. The research focused on Seminar 
presentation student's graduate English program 2015/2016 Academic year. The researcher took all of the participants from September until November; the researcher observed all of the student's presentation to know whether the gender differences of anxiety in Seminar Presentation. After presenting the researcher chose two males and two females' student by some consideration such as: (1) the students look unwell in presentation, (2) the students look anxious in presentation, (3) the students speak too fast or too slow in the presentation. They are determined based on purposive technique, a particular choice subject as they were believed to facilitate the provision of maximum information for complete data collection. To collect the data of this research, four kinds of the instrument are used namely, observation, recording, field notes, audio video, and interview.

\section{Results}

\subsection{Anxiety is Affected by Gender Differences}

Concerning to the result, it revealed that the gender differences on anxiety only differ in feel and behavior from four differences (fell, act or behavior, think and talk) where think and talk are same when they are in high anxious, man and female have different ways to express their feeling in anxiety, different act or behavior which are also related to the students anxious in using nonverbal language. Tannen, (1990) stated that male and female differ in physical and behavior.

Anxious feeling in presentation generally occurs to everyone in common situation, heart which is beat fast or trembling were the effect of anxious in presentation despite anxious feeling was common for everyone but male and female face anxious differently in presentation where man felt anxious because they think about how to maintain their statement and try to look masculine even though they do not know how to answer the questions.. The researcher divided in two categories, female anxious and male anxious. It is caused by the student's different perception about their performance quality as Tannen, (1990) stated that male and female differ in the way they feel. Another constellation of gender-linked beliefs center on stereotypic ideas about emotional expressions showed that woman were believed express most emotions more readily than was a man (Shibley 2002).

These differences could be caused by different perceptions of men and women style in communication. Females thought men were arrogant whereas males thought females were emotional. These views may be due to differences in men and women's views about the conversation. According to Stanton (2001), women see conversations as the way to develop and preserve intimacy, while for men conversations are negotiations to achieve and maintain power. Generally, life for men is like a contest, a struggle to preserve independence. Therefore, women may tend to think of interactions in a non-hierarchical way while men typically view the world in a hierarchical way such that, during any interaction, one person is in a superior position and the other in an inferior position. According to Hassan (2000), women interact in ways that promote solidarity and equality, whereas men interact in ways which maintain and increase their power and status. Vanfossen (2001:2). Stated these 
characteristics could be found in the learning styles of female and male students as observed above. The high tendency for females to be passive and feel reluctant to speak to different-sex is affected by their emotional and sensitive thoughts. Males' high confidence, on the other hand, is caused by their need to show up as a competitive, independent, and powerful people.

\subsection{Examining Students`Anxiety and Gender Differences}

This part illustrates some extracts from the data obtained through audio recording and seminar observation checklist; the researcher found that there were some differences showed by male and female students in seminar presentation from the first taking the data until the last. The differences covered the theory of Deborah Tannen (1990). Gender differences are apparent physically and behaviorally. Men and woman differ in the way they think, feel, act and talk. The detailed findings were presented below:

\subsubsection{The female feeling in the presentation}

All female students have a different feeling in speaking related to their performance in their seminar presentation. The researcher presented the example of extract as follow:

This extract one below was taken from the first observation by recording. The presenter of this recording was female student $\mathrm{A}$, the student at graduate program of the state university of Makassar. This recording was taken on Thursday, 27th October 2016, at 9:00 a. m.

Iya, pertama. Karena saya memang nervous, memang pada saat itu saya melihat catatan sesekali hal itu yang memebuat saya tambah menjadi nervous, makanya saya nunduk terus pada saat presentasi tapi setelah pertengahan presentasi saya sudah mulai merasa percaya diri dan nervous saya sudah berkurang kemudian saya baru bisa mulai menatap audience. Seperti itu. (Extract 1).

Yes, firstly, because I am absolutely nervous. Actually, I sometimes look at my note. It makes me more nervous. That's way I bow repeatedly when I have my presentation. However, within my ongoing presentation, I feel confident and I lost my nervous a little bit. Then I can observe intently the audience, That is.

From the first extract above, the student felt anxious because she had to divide her concentration. Memang ada sedikit nyontek thooo... jadi nervous nyontek. [I sometimes look at my note. It makes me more nervous]. Cheating is one of the unusual attitude that students did; it makes some students feel worried when they cheated their notes. It supports the findings from Hertz et al (2016) stated that presenters indeed used substantially more text than is advised. Speaking anxiety was found to be related to the time spent on preparing and rehearsing. Generally, female perfectionists, they always call attention to the people who are looking at them while presenting their presentation, especially their body language or body movement. It makes them anxious because they have to force themselves to be perfect. This extract indicates that female students felt under pressure to look for perfection through presentation.

DOI: 10.33750/ijhi.v1i1.6 
Pertama nervous iyaaa ada rasa takut-takut takutnya yahh seminar saya gagal itu yang menjadi ketakutan saya. (Extract 2)

Firstly, I was nervous I worried that my seminar would fail that was what Ifeared of.

In the extract 2 above, it can be seen that the female was anxious before she started her presentation. She has already felt awkward with her presentation. She tried to guess what will happen on her presentation before presented. It supported by her statement. Takut-takut takutnya yahh seminar saya gagal. [ I was nervous I worried that my seminar would fail that was what I feared of]. It supports the finding from Bares et al (2011), stated that male with same level of depression as female had a greater probability of endorsing the items of depressions. It was in line with the statement from Hisao, 2011 the evidence on the effect of gender and statistic anxiety showed that statistic anxiety is higher for females than males in learning English.

\subsubsection{Male feeling in presentation}

All male students have different feeling in speaking related to their performance in seminar presentation. The researcher presented. The example extract as in the following extract 3 . This extract 3 was taken from the observation by recording. The presenter of this recording was male students $\mathrm{B}$ the student at graduate program state university of Makassar. This recording was taken on Thursday, 21st November 2016, at 10:00 a. m.

Mungkin salah bicara salah ngomomng diluar apa di... grammer ndak teratur ituuuu ... (Extract 3)

Perhaps, mis pronouncing ... ungrammatical, that's it....

Nervousmi... makanya monoton satu gayaji... makanya tinggal terus bukanka juga model tho mau tinggal terus eeeeeeee haahhaahah nervouslahhh. (Extract 4)

[Nervous, that's way I got monotone style, so just calm, I was not a model as well who needed to stay along... haha ... so nervous].

From the extract 3 and 4 above it can be seen how male showed his nervousness by telling some jokes, she said. Makanya tinggal terus bukanka juga model tho. [so just calm, I was not a model as well who need to stay along...haha...]. It was supported by Neufron (2007) who stated that male mostly used joke in his speak and tried to tell the fact, he said. Mungkin salah bicara salah ngomomng diluar apa di... grammer ndak teratur ituuuuu... [perhaps, mis pronouncing ... ungrammatical words, that's it...]. It supports the finding from Kitano (2001), notes that the anxiety level of a male student became higher as he perceived himself less competent.

\subsubsection{Male and female behavioral differences}

This part deals with female and male preparation before presentation. This part is divided into two: female preparation and male preparation. They are being exposed one by one in the following section. 


\subsubsection{Female behavior in preparation}

This extract 5 was taken from the third observation by recording. The presenter of this recording was female students B the student at graduate program state university of Makassar. This recording was taken on Thursday, $9^{\text {th }}$ November 2016, at 9:00 a. m.

Tentunya sebelum saya presentasi saya mempunyai banyak persiapan mulai dari persiapan tentang kesiapan saya. Bahkan sebelum saya tampil saya sudah mempersiapkan power point, instrument dan saya memepersiapkan banyak catatan agar saya lebih mengguasai materi suapaya penampilan saya lebih mantap bahkan sebelum presentasi saya mengginap di hotel untuk belajar keras supaya saya betul-betul belajar agar saya lebih mantap lagi. (Exract 5)

Definitely, before presenting, I've got a very well preparation. Instead, my slide show was set up earlier as well as the research instrument. I made note so I could master my paper because I considered my best performance. A day earlier, I stayed at hotel for cramming in order achieve.

This extract 5 was taken also from the third observation by recording. This recording was taken on Thursday, $9^{\text {th }}$ November 2016, at 9:00 a. m.

Seperti ini, penampilan saya disekolah memang seperti itu, menurut saya penampilan sangat berpengaruh, apalagi di tempat saya menggajar anakanak bias menilai penampilan saya makanya say harus menyesuaikan penampilan saya, karena anak-anak SMA bias menilai banyak hal tentang penempilan. Buat saya penampilan itu sangat berpengaruh sekali terhadap penampilan. Jadi satu minggu sebelum saya presentasi saya sudah menyetrika pakaian saya dengan baik sepatu saya siapkan baik baik untuk persiapan presentasi minggu depan, jadi semuanya di persiapkan dengan baik. (Extract 6)

Like this way, my appearance is like... right now. For me, appearance is exceptional. The students even could measure my appearance. That is way I should make I up because high school learners are able to evaluate many things especially appearance. So, a week earlier, I had ironed my clothes and got every thing 's up like my shoes. Those were for my presentation for the following week. So, everything was well prepared.

From the extract 5 and 6 above, it can be seen that female fashion was one of the important things which supported her presentation she thought fashion gave more confidence. Preparing materials, power point and some notes will support the presentation. However, in anxiety case female with over preparations will make her stress and panic because she was disturbing to think the perfectness and master on her presentations. It supports the finding from Pena et al (2016) that female are usually under pressure thinking of their presentation in some reasons that they require to succeed academically and more afraid of failing in some situations, test or presentation. Park et al (2013) also stated that females reported higher anxiety levels compared to males even

DOI: $10.33750 /$ ijhi.v111.6 
females and high anxiety students received higher grades than males and low anxiety students.

\subsubsection{Male behavior in preparation}

This extract was taken from the first observation by recording. The presenter of this recording was male student A the student at graduate program state university of Makassar. This recording was taken on Thursday, 17th October 2016, at 9:00 a. m.

Diri pribadi saya sendiri yang kedua materi saya yg ketiga aa apa... menggenai konsusmsi strategi yang bakalan saya gunnakan pada saat presentasi nantinya pada saat menjawab pertanyaan.(Extract 7)

I myself, the second is my material, the third is about the meals and the strategy that I will be used when I present as well as in answering the questions.

This extract was taken from the first observation by recording. The presenter of this recording was male student A at graduate program state university of Makassar. This recording was taken on Thursday, 21 st November 2016, at 9:00 a. m.

Kalau saya persiapanku mengaji sholat... hahhahahahahahaha dzikir bahhhh belajar baca- baca ji sedikit tho... itu perbanyak sholat menggaji berdoa... iyo...nabilang pak TJ tho perbanyak saja dzikirmu doa. (Extract 8)

About my own preparations are reading Qura 'an, praying, doing dzikir, studying a little bit, that is... praying reciting Quran frequently. Sir TJ said just do dzikir more.

From the extract 7 and 8 above it can be seen how man made their preparation as simple as they can where some of male students just focus on strategies which can be used in presentation. It can be seen when he said. Strategi yang bakalan saya gunnakan pada saat presentasi nantinya pada saat menjawab pertanyaan. [The strategy that I will be used when I present as well as in answering the questions]. It means that male students only focus to maintain his statement and tried to keep his masculine when presented the material. It supports the finding from Udo, et al (2004) stated that there were differences cohort in earlier studies between males and female, it confirm earlier in this finding that female is more Science Anxiety than male. Joking was one of the characters that close with male students as one of the character of male, he said. Kalau saya persiapanku menggaji sholat... hahhahahahahahaha (laugh), dzikir bahhhh belajar baca-baca ji sedikit tho... itu perbanyak sholat menggaji berdoa... iyooooo (agree)... nabilang pak TJ tho perbanyak saja dzikirmu doa. [About my own preparations are reading Qura 'an, praying, doing dzikir ,studying a little bit that is... praying reciting Quran frequently . Sir TJ said just do dzikir more]. Despite joke was common done by everyone but it is close with male. 
a) Drawing without reason (extract 9)

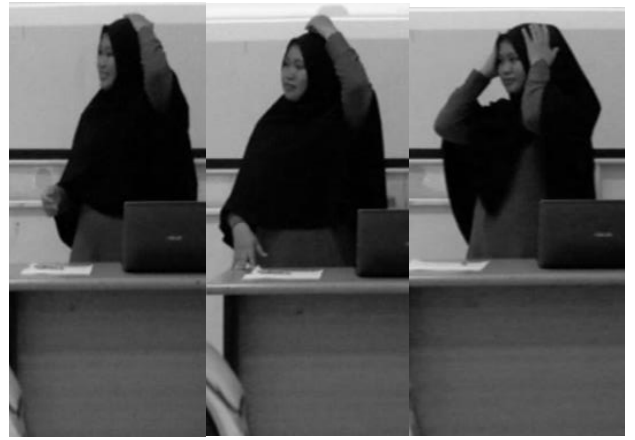

Figure 1. Extract 9

The Figure 1 above showed how female tried to decrease her anxious by touching her veil many times. From the first until the seminar running she tried to touch her veil with her left-hand many times without any reason. It indicated that she tried to control her anxious by touch her veil and she also moved her feet to the left while she moved her fingers and at the last of the seminar she tried to use both of her hands to touch her head and drew back her left feet together with the right foot while showed deep expression on her face. It supports the finding from Nur (1993), that anxiety is a general symptom that can be rooted in the previous failure, being afraid to ankle mistakes to be a citizen, being afraid to lose face or lack self-confidence. This can block the student's performance in speaking. Chaplin (2009) emphasize that anxiety, worry, and oversensitivity symptom are found more strongly for girls than for boys.

b) Holding right hand, holding waist, putting a hand behind (extra 10)

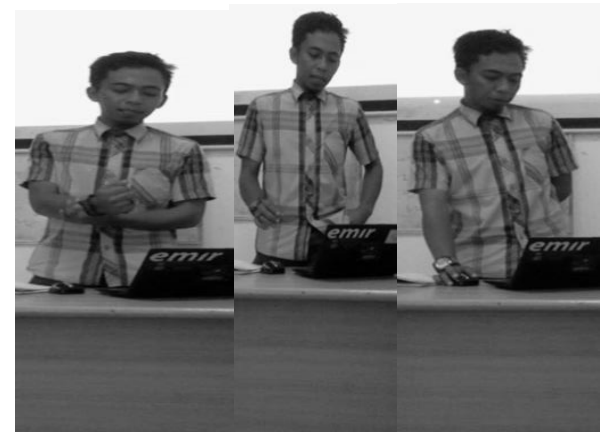

Figure 2. Extract 10

From the picture above it can be seen how male has different behavior in presentation related to his anxious. The first picture showed that he hold his left finger and rolled while speaking and the second picture showed where he 
puts his hand in the pocket. In some research, it also found that men will put both of hands in the pockets as signals that they are not open, doesn't want to talk or engage in the conversation (Mehrabian, 2010). The statement above also supported from Bhui et al (2000) that male and female have different activity in long duration where male confers protection against everyday mood and anxiety states while female found no such protection

c) Holding hands together while thinking (extract 11)

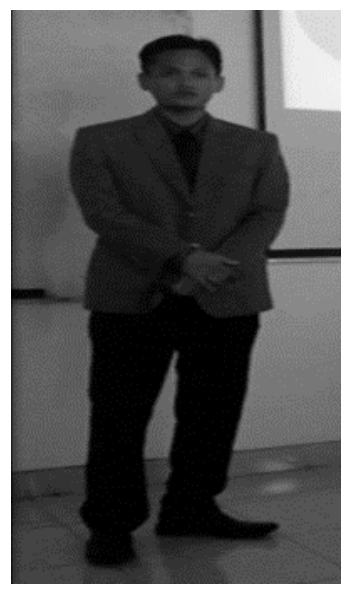

Figure 3. Extract 11

From the picture above, it can be seen how male felt anxious in the presentation. It showed that male just stayed calm and did not move like what female did. Holding hands was one of the males` specific character to show his masculine although some statements said that Men tend to be more expansive in their posture, and more open - taking up more space (Riggio 2012), but when male in high anxiety he preferred to stay calm in deep expression, and he just used his eye contact as expression to express his understanding. In some research, it was also found the man could shifting eyes at the very least maybe lack of confidence or at worst it is an indication of a deception (Philip, 2003).

\section{Conclusion}

This paper has discussed the students anxiety and gender differences in a seminar presentation. The research of anxiety in presentation between male and female students at Graduate Program State University of Makassar covered theory of Tannen (1990), where male and female are different from the way they think, feel, act and talk. On the contrary, in anxiety case where male and female only differ in the way, they feel and act, and they have similarity in the way they think and talk. There is a significant correlation between anxiety and gender where female students had high anxiety based on their feeling while male felt high anxiety because of the effect of their thought. The highly anxious female students have different behavior with the high anxious male students in expressing their anxiety in speaking. The high 
anxious female students did much preparation and thought over about the possible thing that may happen in her presentation and showed some panic expressions, while high anxious male students felt anxious when he could not maintain his statement.

\section{REFERENCES}

Aida.Y. 1994. Examination of Horwitz, horwitz, and Cope's construct of language anxiety: the case of students of Japanese. The modern language journal, 78,155168.

Angle, J. \& Hesse-biber, S. 1981. Gender and Prestige Preference in Language. Plenum Publishing Corporation, 7(4), 449-461.

Arifin,U.N. 2011. The Effect of Anxiety on Students English Learning at SMA Muhammadiyah 6 Makassar. Thesis. Unpublished. Makassar: Graduate Program State University of Makassar.

Aydin, Selami. 2008. An investigation on the language anxiety and fear or negative evaluation among Turkish EFL learners, Asian EFL journal volume 31 article 2, 2008.

Bares, et.al. 2011. Differential items functioning due to gender between depression and anxiety items among Chilean adolescents. International Journal of Social psychiatry 58(4) 386-392.

Bhui.K, Fletcher.A. 2000. Common Mood and Anxiety States: Gender Differences of in the protective effect of physical activity. Psychiatry Psychiatry Epidemiol, 35: 28-35.

Calvarese,M. 2015. The Effect of Gender on stress factors: An Explanatory Study among University Students, Social Science, 2015, 4, 1177-1184.

Chaplin, T. M \& Gillham, J. E. 2009. A Longitudinal Study of Early Adolescents. Journal Early Adolescence, 29, 307-327.

Gardner, M. 1999. Language anxiety. New York: McGraw Hill.

Goldsmith, B.2013. Psychology Today: Men, Women, Emotions and Communication. (Online) (http://www.livestrong.com/article/188130-male-and-femalecommunication/) .Accessed 15 July 2016.

Graham, S., Rees, F., Graham, S., \& Rees, F. 1995. Gender differences in language learning : the question of control. The Language Learning Journal, 11(1), 18-19.

Griffin, M.A., D. McGahee, and J. Slate. 1999 Gender Differences in Nonverbal Communication: Valdosta State University.

Harmer, J. 1992. 'How to teach ', <http:// www.njcu.edu/cill/vol6/courtnly.html>, Accessed 21 July 2016.

Hassan, I.H. 2000. Language, Gender, and Power: Analysis of Theme and Topic Management in Arabic Conversational Discourse. The Humanities and Social Science, 61: 591.

Hertz, et.al. 2016. Power Point Slide as Speaking Notes: The Influence of Speaking Anxiety on the Use of the Text on the Slide. Business and Professional Communication Quarterly 1-12.

Hsiao,et.al. 2011. Gender Differences in Statistics Anxiety among graduate Students Learning English as Foreign Language. Social Behavior and personality, 2011, 39(1), 41-42. 
Kitano,K. 2001. Anxiety in the College Japanese Language Classroom. The Modern Language Journal, 85, 500-543.

McLean, C. P., \& Anderson, E. R.2009. Brave men and timid women? A review of the gender differences in fear and anxiety. Clinical Psychology Review, 29, 496-505.

Mehrabian, Albert. 2010 .Vocal Power and Body Language Intelligence for Professionals. Los Angeles: Kmc Brand Innovation.

Moleong, Lexy J. 2004. Metode Penelitian Kualitatif. Bandung: PT Remaja Rosdakarya.

Neuforn, D. S. V. 2007. Gender Gap in the Perception of Communication in Virtual Learning Environments. Interactive Learning Environments, 15(3), 209-215.

Nur,J Hafsah. 1993. Affective Factor in Language Learning in Indonesia. Ujung Pandang: FBS IKIP Ujung Pandang.

Padmadewi, N. N. 1998. Students Anxiety in Speaking Class and Ways of Minimizing it', Journal ilmu pendidikan 5, 60-67.

Pena,Pelluciani \& Bono. 2016. Gender differences in test anxiety and their impact on higher educatioon students`academis achievement. Procedia-Social and behavioral science 228 (2016) 154-160.

Philip, Headread. 2003. How to Read Body Language, EBooks at Metro.com

Park et.al 2013. Gender Differences in the Foreign Language Classroom Anxiety Scale. Scivers Science Direct 41 (2013) 462-471.

Sherwood,S. 2012. 10 Ways the Body Speaks: Men and Women Communicate Differently. (Online)(http://www.livestrong.com/article/188130-male-and-femalecommunication/, Accessed 15 July 2016).

Shibley. J., Pope.K Gender differences in language learning: the question of control., Reid.P.T., Riger.S., Hucles.J.S., Toner.B ., Travis. C. V. 2002. Women Gender. (J. Worell, Ed.). Academic Press.

Stanton, A. 2001. Men and Women in Conversation: Finding a Way to Bridge the Gap, University of Massachusetts. http://www.healthandage.com/public/healthcenter/28/article/1284/Men-and-Women-in-Conversation-Finding-a-Way.html. Accessed 10 July 2008.

Syarifuddin 2006, thse effect of self -esteem, anxiety and gender on oral communication of English foreign language students of Universitas negeri Makassar. Unpublished dissertation. Makassar: Universitas Hasanuddin.

Tannen, D. 1990. You Just Don't Understand: Women and Men in Conversation. New York: Morrow.

Tutyandari, C.2005. Breaking the silence of the students in an English language class, (Presented paper at the 53rd TEFLIN international conference edn; Yogyakarta, Indonesia.)

Udo, et.al. 2004. Science Anxiety and Gender in Students Talking General Education Science Courses. Journal of Science Education and Technology, Vol. 13, No. 4,

Vanfossen, Beth. 2001. Gender Differences in Communication. ITROW's Women and Expression Conference. 